\title{
PERAN ORANG TUA DALAM PENDAMPINGAN ANAK USIA SD/MI DALAM PEMBELAJARAN ONLINE DI SAAT PANDEMI COVID-19
}

\author{
Eka Rahayu ${ }^{1}$ \\ Vivin Agustin Anggraini ${ }^{2}$ \\ Siti Nurhasanatul Islam ${ }^{3}$ \\ eka.rahayu0792@gmail.com ${ }^{2}$,
}

\begin{abstract}
This article aims to find out what parents role while accompanying children during the Covid-19 pandemic. The method used is a case study through filling out a questionnaire. The results showed that in general, the role of parents was as a guide, educator, carer, developer and supervisor. In particular, the roles that arise are: maintaining and ensuring children to continue learning even though it is done online, assisting children in doing school work, doing joint activities while at home, creating a comfortable environment for children, establishing intense communication with children, guiding and motivating children, provide education. Guidance is needed for parents to help support children's needs-based activities during the pandemic. Keywords: role of parents, online learning, pandemic period
\end{abstract}

\begin{abstract}
Abstrak
Artikel ini bertujuan untuk mengetahui apa saja peran orang tua selama mendampingi anak belajar di masa pandemi Covid-19. Metode yang digunakan dalam penelitian ini adalah studi kasus melalui pengisian kuesioner. Hasil penelitian menunjukkan bahwa secara umum peran orangtua adalah sebagai pembimbing, pendidik, penjaga, pengembang dan pengawas. Secara khusus peran yang muncul yaitu: menjaga dan memastikan anak untuk tetap belajar di rumah meskipun dilakukan secara online, mendampingi anak dalam mengerjakan tugas sekolah, melakukan kegiatan bersama selama di rumah, menciptakan lingkungan yang nyaman untuk anak, menjalin komunikasi dengan anak, membimbing dan memotivasi anak, memberikan edukasi. Diperlukan panduan bagi orang tua dalam membantu mendampingi kegiatan anak yang berbasis pada kebutuhan anak selama pandemi.
\end{abstract}

Kata kunci: peran orang tua, belajar online, masa pandemi

\section{Pendahuluan}

Semua aspek kehidupan saat ini disibukkan dengan munculnya Corona Virus Desease (Covid-19). Indonesia termasuk salah satu negara yang terkena dampak virus tersebut. Pemerintah berusaha secara kontinu untuk memutus mata rantai penyebaran virus ini. Upaya yang dilakukan pemerintah salah satunya adalah dengan mengeluarkan PP Nomor 21 tahun 2020 tentang Pembatasan Sosial Berskala Besar Dalam Rangka Percepatan Penanganan Covid-19.

\footnotetext{
${ }^{1}$ Dosen Tadris Matematika, Fakultas Tadris Umum Universitas Islam Zainul Hasan

${ }^{2}$ Dosen Tadris Matematika, Fakultas Tadris Umum Universitas Islam Zainul Hasan

${ }^{3}$ Mahasiswa Tadris Matematika, Fakultas Tadris Umum Universitas Islam Zainul Hasan

37 | Jurnal Auladuna
} 


\section{Eka Rahayn \\ Vivin Agustin Anggraini \\ Siti Nurhasanatul Islam}

Keluarnya PP tersebut berakibat pada pembatasan berbagai aktivitas termasuk proses belajar mengajar di sekolah. Aktivitas Belajar siswa dilakukan secara daring (dalam jaringan) atau online setelah resmi dikeluarkan Surat Edaran Mendikbud Nomor 36962/MPK.A/HK/2020 tentang pembelajaran secara daring dan bekerja dari rumah dalam rangka pencegahan penyebaran Covid19. Kebijakan ini mewajibkan guru tetap bekerja dari rumah siswa belajar dari rumah dimulai dari jenjang PAUD sampai Perguruan Tinggi (kemdikbud.go.id, 2020). Kebijakan tersebut tentunya tidak hanya berdampak pada relasi guru dan murid selama belajar online, namun juga memaksa peran orang tua dalam pelaksanaan belajar online dari rumah.

Orang tua berperan dalam mendampingi keberhasilan dan kesuksesan anak selama belajar di rumah ${ }^{4}$. Awalnya peran orang tua adalah membimbing sikap serta keterampilan yang mendasar, seperti pendidikan agama untuk patuh terhadap aturan, dan untuk pembiasaan yang baik. Sementara dengan belajar di rumah adalah membutuhkan peran penting orangtua secara optimal yaitu sebagai pendamping pendidikan akademik.

Membahas tentang peran orang tua saat ini sangatlah luas . Dilihat dari fungsinya keluarga memiliki tugas dan fungsi perawatan, dukungan emosi dan materi, serta pemenuhan peranan tertentu. Keluarga merupakan bagian penting dari unit masyarakat. Keluarga memiliki peran penting dalam merawat, mendidik, melindungi dan mengasuh anak ${ }^{5}$. Pembentukan karakter dan perilaku anak sangat bergantung pada pengasuhan orang tua. Apabila terdapat kesalahan pengasuhan maka dampaknya akan terlihat ketika anak sudah dewasa. Pengasuhan anak adalah interaksi antara orang tua dan anak dengan proses yang berkelanjutan untuk mendorong pertumbuhan serta perkembangannya yang optimal.

Paparan di atas menunjukkan bahwa selama ini, peran orang tua lebih menonjol dalam bidang pengasuhan dan perawatan, sementara pendidikan akademik seringkali dialih tugaskan kepada pihak kedua yaitu lembaga pendidikan. Kebanyakan orang tua merasa bahwa kewajiban dalam mendidik anak telah usai setelah anak dimasukan ke suatu lembaga pendidikan ${ }^{6}$. Padahal orang tua dapat membimbing anak dan melanjutkan program yang sudah dilakukan di sekolah ${ }^{7}$.

\footnotetext{
${ }^{4}$ Rumbewas, S. F., Laka, B. M., Moekbun, N. 2018. Peran Orang Tua dalam Meningkatkan Motivasi Belajar Peserta Didik di SD Negeri Saribi. Jurnal EduMatSains. Vol. 2. No. 2, Januari, Hal. 201

${ }^{5}$ Yulianti, T. R. 2014. Peran Orang Tua dalam Mengembangkan Kreativitas Anak Usia Dini (Studi Kasus Pada Pos PAUD Melati 13 Kelurahan Padasuka Kecamatan Cimahi Tengah). Jurnal Empowerment. Vol. 4. No. 1, Februari. Hal. 12

${ }^{6}$ Sari, Diana. 2017. Peran Orang Tua dalam Memotivasi Belajar Siswa. Prosiding Seminar Nasional. Universitas PGRI Palembang. November. Hal. 41.

${ }^{7}$ Umar, Munirwan. 2015. Peranan Orang Tua dalam Peningkatan Prestasi Belajar Anak. Jurnal ilmiah edukasi. Vol. 1. No. 1, Juni. Hal. 20
} 
Belajar di rumah membuat banyak orang tua menemukan kesulitan dalam mengajari anak tentang materi yang diberikan guru. Hal tersebut dikarenakan banyak dari anak belum terbiasa dengan belajar online. Anak yang biasanya dapat berinteraksi langsung dengan gurunya, harus terbiasa dengan melihat komputer atau smartphone selama pembelajaran online berlangsung. Selain itu, banyak dari orang tua yang tidak terbiasa dengan mata pelajaran anak-anak mereka karena selama ini guru yang mengajar ${ }^{8}$. Selain masalah tersebut, beberapa wali murid merasa terbebani dan mengeluh karena tugas anak yang banyak dan berat dari pihak sekolah". Apalagi dengan orang tua yang kesehariannya harus bekerja di suatu instansi.

Berdasarkan hal tersebut di atas, kajian dalam penelitian ini sangatlah penting dilakukan untuk mengetahui sejauh mana peran orang tua dalam mendampingi putra-putrinya belajar dari rumah saat terjadi pandemi Covid-19. Penelitian ini menggunakan metode studi kasus karena sangat sesuai untuk menjawab pertanyaan "bagaimana"peran orang tua dalam mendampingi anak selama belajar dimasa pandemi Covid-19. Subjek dalam penelitian ini adalah orang tua yang memiliki anak usia SD/MI. Teknik pengumpulan data adalah dengan mengisi kuisioner yang dibagikan peneliti melalui aplikasi Google Form.

\section{Pembahasan}

Peristiwa pandemi Covid-19 yang terjadi dihampir seluruh dunia ini khususnya di Indonesia, menunjukkan bahwa peran orang tua atau keluarga dalam mengasuh, merawat dan juga mendidik anak sangatlah penting. Hal tersebut mengembalikan fungsi awal keluarga yaitu sebagai pusat segala kegiatan, tempat terjadinya pendidikan yang utama untuk anak.

Keluarga merupakan tempat tumbuh kembang anak yang utama. Di dalam keluarga terdapat nilai agama, moral, serta sosial dapat dilakukan lebih efektif dari pada dilakukan di lembaga lain. Keluarga berperan penting dalam menanamkan kebiasaan dan pola tingkah laku, serta menanamkan nilai, agama, dan moral sesuai dengan usia dan kultur di keluarganya. Keluarga memiliki fungsi cinta dan kasih sayang, perlindungan, pendidikan, nilai, agama, moral, serta sosial $^{10}$. Keluarga merupakan tempat utama atau tempat awal dan tempat terdekat anak, karena dalam keluarga tersedia banyak waktu luang untuk dihabiskan bersama dengan anak. Keluarga menjadi satu bagian yang paling penting dalam menjadikan anak lebih baik salah satunya adalah dengan pendidikan, keluarga menjadi salah satu pusat pendidikan untuk anak. Secara lebih

\footnotetext{
${ }^{8}$ Ndani, A. R. 2020. Kenapa ya Orang Tua Kadang Bisa Jadi Guru Terburuk Untuk Anaknya Sendiri? Diadona. ${ }^{9}$ Rahma, I. H. 2020. Pemerhati Soroti Para Ibu yang Keluhkan Tugas Anak Saat Belajar di Rumah. Tribunnews.com. 10 Warisah, Yusmi. 2015. Pentingnya "Pendampingan Dialogis" Orang Tua dalam Penggunaan Gadget Pada Anak Usia Dini. Prosiding Seminar Nasional Pendidikan. Universitas Muhammadiyah Ponorogo. November. Hal. 136 39 | Jurnal Auladuna
} 
Eka Rahayu

Vivin Agustin Anggraini

Siti Nurbasanatul Islam

spesifik, peran orang tua yang tercermin selama terjadinya masa pandemi Covid-19 akan di paparkan dibawah ini.

\section{Menjaga Kesehatan pada saat Pandemi}

Setiap orang tua pasti menginginkan anaknya selalu sehat, apalagi dalam kondisi pandemi saat ini yang membuat orang tua menjadi semakin khawatir. Caranya yaitu dengan mengingatkan dan mengajarkan anak untuk selalu menerapkan pola hidup bersih, selalu menjaga kesehatan serta mengikuti protokol kesehatan. Hal tersebut dilakukan agar selalu sehat dan terhindar dari berbagai penyakit. Orang tua dapat memberikan contoh yang baik pada anak, memberikan peringatan dan nasihat agar selalu hidup bersih dan sehat.

Perlakuan orang tua yang selalu memberikan pengertian dan latihan kepada anak tentang kebersihan dan kesehatan, membuat anak selalu menjaga kebersihan diri. Tidak cukup hanya dengan mengingatkan saja, orang tua berperan untuk menjaga anak tetap sehat dan menerapkan pola hidup sehat dengan benar. Orang tua memberikan kasih sayang kepada anaknya tidak hanya dalam bentuk pendidikan, tetapi juga penting untuk selalu mengontrol perkembangan anaknya. Seperti yang kita tahu anak bisa lebih cepat belajar dengan meniru, sehingga keteladanan dan pembiasaan penting untuk dilakukan ${ }^{11}$. Orang tua dapat memberikan contoh selalu mencuci tangan setelah beraktifitas di luar ruangan. Hal tersebut dinilai penting untuk meningkatkan kesadaran mengenai kebersihan lingkungan. Selain itu, orang tua dapat memastikan anak mengonsumsi makanan yang bergizi, tidur teratur, serta memakai masker saat beraktifitas di luar rumah.

\section{Mendampingi dalam Pelaksanaan Belajar Online}

Menteri Pendidikan dan Kebudayaan mengeluarkan kebijakan untuk memutus mata rantai penularan virus corona di sekolah dengan pembelajaran online dari rumah. Sementara waktu orang tua menggantikan peran guru dalam mendampingi anak belajar di rumah. Berdasarkan hasil kuesioner bahwa selama sekolah online ini orang tua lebih banyak membantu mengerjakan tugas yang diberikan oleh guru. Kondisi tersebut menunjukkan bahwa kegiatan sekolah online yang diberikan guru lebih pada pemberian tugas. Seperti yang diungkapkan "kegiatan yang diberikan oleh lembaga sekolah dalam penerapan pembelajaran di rumah salah satunya adalah pemberian tugas atau penugasan".

\footnotetext{
${ }^{11}$ Wulandari, Y., Kristiawan, M. 2017. Strategi Sekolah dalam Penguatan Pendidikan Karakter bagi Siswa dengan Memaksimalkan Peran Orang Tua. Jurnal Manajemen, Kepemimpinan, dan Supervisi Pendidikan. Vol. 2. No. 2, Juli, 293
} 
Hal tersebut sangatlah menarik untuk dikaji. Dengan pemberian tugas seperti itu apakah artinya peran pendampingan belajar anak dapat dikatakan berhasil?. Tidak hanya mendampingi anak dalam mengerjakan tugas tetapi juga orang tua membantu anak dalam memahami materi yang diberikan guru dalam bentuk slide power point atau video pembelajaran. Orientasi pendampingan yang terfokus pada pengerjaan tugas sekolah menunjukkan bahwasannya orientasi pendidikan di Indonesia masih menekankan pada aspek perkembangan kognitif saja. Sementara perkembangan afeksi dan psikomotor dapat dikatakan tidak menjadi prioritas sehingga kurang terstimulasi. Proses pembelajaran di rumah diharapkan guru serta orang tua dapat mewujudkan pendidikan tidak hanya berfokus pada pencapaian akademik saja. Namun dapat mewujudkan pendidikan yang bermakna agar tujuan pendidikan dapat tercapai. Dibutuhkan saling pengertian dari pemerintah, sekolah, serta masyarakat untuk saling bersinergi.

\section{Melakukan Kegiatan Bersama Selama di Rumah}

Beberapa cara agar orang tua dapat meningkatkan proses pengasuhan dimasa pandemi ini, salah satunya adalah dengan membuat kegiatan yang berkualitas bersama anak. Terdapat beragam kegiatan yang dapat dilakukan bersama orang tua selama pandemi berlangsung, seperti menyapu rumah, memasak bersama, mencuci piring, bermain, beribadah, dan sebagainya. Kegiatan ini memberikan kesempatan bagi orang tua dan anak untuk mempererat ikatan satu dengan lainnya yang selama ini orangtua hanya sibuk bekerja dan anak sibuk belajar di sekolah. Sebagai contoh untuk anak usia SD/MI adalah dengan melibatkan anak dalam pekerjaan rumah seperti membersihkan rumah atau memasak yang dapat dikombinasikan dengan permainan yang seru. Dalam hal ini orang tua berperan sebagai pengembang berbagai kegiatan yang bisa dilakukan bersama anak.

Kualitas waktu yang dimiliki orang tua dan anak selama masa pandemi dapat dimanfaatkan untuk membangun kebersamaan antar anggota keluarga. Kebersamaan orang tua sangat diperlukan karena orang tua yang seharusnya lebih memahami akan tingkatan perkembangan serta hal-hal yang dibutuhkan seorang anak. Kebersamaan dengan anak dimulai sejak anak di dalam kandungan hingga remaja ataupun dewasa dengan disesuaikan kebutuhan dari masing-masing anak. Kesibukan sehari-hari orang tua sering mengakibatkan waktu bersama anak menjadi terbatas. Bahkan di hari libur, ketika semua anggota keluarga berkumpul, masingmasing orang tua masih disibukkan dengan aktivitas pekerjaanyanya. Dengan demikian peran orang tua sebagai pengembang kegiatan dapat melibatkan anak-anak dalam menentukan variasi kegiatan. Hal tersebut dilakukan untuk menghindari anak dari perasaan jenuh dan bosan karena 41 | Jurnal Auladuna 
harus berdiam diri di rumah dalam beberapa waktu lama dan belum bisa ditentukan sampai kapan pandemi ini berakhir.

\section{Menciptakan Lingkungan yang Nyaman untuk Anak}

Lingkungan dan suasana yang nyaman perlu diciptakan orangtua untuk perkembangan seorang anak baik secara fisik maupun psikologis. Pastinya orangtua adalah orang yang paling memahami karakter anaknya serta kapan anaknya harus belajar dan mengerjakan tugas dari guru.

Peran orangtua dalam menciptakan lingkungan yang bersih, sehat, aman, nyaman dan menyenangkan sangatlah penting. Tidak perlu dengan kata kasar atau nada tinggi untuk menginstruksikan sesuatu kepada seorang anak, tetapi dengan menggunakan bahasa yang mudah dipahami dan memberikan arahan serta nasehat pentingnya belajar untuk masa depan seorang anak. Misalnya dengan mengobrol dan melakukan hal yang disukai anak selama itu bernilai positif. Jika anak sudah merasa nyaman dengan kondisinya barulah orangtua

\section{Menjalin Komunikasi dengan Anak}

Peran orang tua salah satunya adalah menjalin komunikasi yang baik dengan anak. Menjalin komunikasi yang dilakukan orang tua dan anak menjadi hal penting karena dengan begitu akan mempererat hubungan orang tua dan anak. Melalui komunikasi, maka orangtua akan dapat mengetahui keinginan anak serta orang tua dapat menyampaikan apa yang diinginkan atau harapan serta motivasi kepada anak. Dengan begitu anak akan semakin terbuka kepada orang tua, begitupun sebaliknya orang tua akan semakin terbuka kepada anaknya, hal tersebut dapat membuat suasana keluarga yang hangat dan nyaman.

Komunikasi yang positif akan membangun pola asuh yang positif pula dalam keluarga. Hal tersebut ditunjukkan dengan cara mendengarkan dengan penuh perhatian serta fokus terhadap pembicaraan sang anak. Komunikasi dapat dikatakan efektif apabila dalam kegiatan komunikasi, orang tua menghindari kesalahan saat berkomunikasi khususnya pada saat proses mendidik anak. Ketika bermain, kegiatan mendengarkan dan mengobrol dengan penuh kasih saying akan menimbulkan komunikasi positif antara orang tua dan anaknya. Salah satu peran keluarga adalah menciptakan lingkungan yang menyenangkan untuk belajar di rumah, serta menjalin hubungan dan komunikasi hangat dan penuh kasih sayang bersama anak. Dengan begitu anak akan merasa diperhatikan dan selalu bahagia berada di lingkungan keluarga. 


\section{Belajar bersama Keluarga}

Bagi orang tua yang memiliki anak usia PAUD atau SD/MI sangatlah menyenangkan memiliki banyak waktu bersama anak karena masa keemasan seorang anak berada pada usia tersebut. Orang tua dapat memahami perkembangan karakter seorang anak, tumbuh kembang fisik dan psikisnya serta bakat dan minat yang dimiliki seorang anak. Pada hakikatnya seorang anak lebih senang bermain dari pada belajar, maka dari itu orang tua harus pintar dalam menyisipkan pengetahuan akademik dalam kegiatan bermain anak. Anak dapat banyak belajar tentang sesuatu melalui kegiatan bermain, dan bermain juga salah satu bagian dari pertumbuhan dan perkembangan anak yang sangat penting. Dunia anak adalah bermain, melalui bermain, menuntun pada perkembangan anak yang cerdas, ceria dan selalu sehat. Sebagian besar anak-anak menggunakan waktunya untuk bermain, baik itu bermain sendiri maupun dengan temannya.

Kegiatan bermain bersama akan mendorong anak-anak untuk berperilaku positif sesuai dengan kebutuhan dan harapan. Selain itu diharapkan pula hubungan yang terjalin saat bermain bersama akan secara konsisten dapat mencegah perilaku negatif serta sebagai salah satu cara membangun dan mempertahankan suasana keluarga yang nyaman di rumah. Kebersamaan dan keakraban dalam keluarga akan membangun pengasuhan dan perawatan yang positif, yang mana didalamnya mengandung pola asuh dengan penuh kasih sayang.

\section{Menjadi Panutan bagi Anak}

Orangtua adalah panutan bagi anak dalam keluarga karena orangtua adalah orang paling dewasa dibandingkan seorang anak. Anak-anak akan selalu mengikuti gaya berbicara, sikap dan perilaku orangtuanya yang dilihat dan didengar setiap hari. Apalagi anak usia SD/MI belum memahami sikap dan perilaku orangtua tersebut bernilai positif atau negatif. Sehingga orangtua adalah sumber atau referensi pertama bagi anak untu belajar bagaimana berbicara dan bersikap dengan sopan dan santun.

Orangtua berperan penuh dalam membimbing dan mendidik anak agat dapat menjalankan perannya sebagai makhluk sosial. Dalam kehidupan bermasyarakat, seorang anak diperlukan perkembangan moral yang baik sehingga sangatlah penting orangtua menjadi panutan dan contoh dalam hal apapun. Peran orangtua sebagai panutan akan mendorong anak bersikap dan berperilaku positif sesuai harapan yang diinginkan. 
Eka Rabayn

Vivin Agustin Anggraini

Siti Nurbasanatul Islam

\section{Memberikan Pengawasan pada Anggota Keluarga}

Fungsi pengawasan dilakukan orang tua terhadap pola perilaku hidup bersih dan sehat dan pelaksanaan kegiatan belajar anak. Peran pengawasan menunjukkan bahwa dalam keluarga atau orang tua merupakan interaksi orang tua dengan anak, yang di dalamnya berperan untuk melindungi, membesarkan dan mendisiplinkan anak. Fungsi keluarga adalah untuk melindungi dengan menumbuhkan dan memberikan rasa aman dalam keluarga baik secara fisik, ekonomi, dan psikososial, serta kehangatan. Bentuk dari melindungi anggota keluarga di sini, orang tua sekaligus berperan sebagai pengawas anak-anaknya dari hal-hal yang membuat anak tidak aman ataupun yang lainnya.

Peran pengawasan merupakan salah satu cara untuk melindungi anggota keluarga. Peran ini berkaitan dengan dimensi pemahaman dan penerimaan untuk tidak menghakimi, serta melibatkan perhatian penuh dari berbagai atribusi dan harapan yang dibuat orang tua berkaitan dengan persepsi interaksi pengasuhan. Persepsi interaksi pengasuhan yang positif terjadi ketika adanya pemahaman dan penerimaan antara anak dengan orang tua sehingga memberikan rasa aman untuk anak.

\section{Menafkahi dan Memenuhi Kebutuhan Keluarga}

Di saat pandemi seperti sekarang ini, tidak sedikit orangtua yang kehilangan pekerjaan dan kesusahan dalam memenuhi kebutuhan keluarga. Sehingga diperlukan kerja sama yang baik antara ayah, ibu, kakak atau anggota keluarga lain dalam menyambung hidup serta tetap mementingkan pendidikan anak. Semua anggota keluarga harus saling mendukung dan menguatkan satu sama lain. Kesehatan adalah hal yang sangat penting saat ini sehingga diperlukan banyak makanan bernutrisi serta vitamin untuk menjaga imun atau daya tahan tubuh agar tidak mudah terserang virus atau penyakit. Hal tersebut membutuhkan finansial yang lebih dibandingkan sebelum masa pandemi.

Kebutuhan keluarga yang kurang atau tidak dapat terpenuhi akan mengganggu keharmonisan. Ketidakberfungsian keluarga dalam memenuhi kebutuhan dasar akan berdampak pada psikis seorang anak. Upaya keluarga dalam mencukupi kebutuhan merupakan bagian dari pengasuhan positif, yang mana hubungan dibangun terus-menerus antara orang tua dan anak atau antar anak-anak yang termasuk di dalamnya mengasuh, merawat, mengajar, memimpin, berkomunikasi, dan menyediakan kebutuhan anak secara konsisten dan teratur. 


\section{Membimbing dan Memberi Motivasi Kepada Anak}

Kegiatan belajar dari rumah yang dilakukan anak-anak selama pandemi berlangsung memunculkan beragam kondisi diantaranya adalah kebosanan serta menurunnya semangat anakanak dalam belajar. Seperti yang disebutkan dalam penelitian bahwa dampak dari situasi pandemi Covid-19 pada peserta didik adalah kejenuhan dan kebosanan. Dalam hal ini peran orang tua adalah membimbing dan memberikan motivasi kepada anak, agar anak tetap bersemangat dalam melakukan kegiatan belajar di rumah. Pada dasarnya anak memiliki motivasi untuk melakukan suatu hal yang positif, apabila ia mendapatkan sebuah dorongan atau dukungan dari orang-orang terdekat seperti orang tua. Motivasi adalah serangkaian usaha dalam menciptakan keadaan untuk memberi rangsangan agar seseorang ingin melakukan sesuatu. Peran-peran ini dimunculkan oleh orang tua, sebagai salah satu cara pengasuhan orang tua terhadap anaknya. Sebagaimana dipaparkan oleh beberapa orang tua di bawah ini.

\section{Memberikan Edukasi}

Terdapat beberapa fungsi keluarga, salah satunya fungsi sosialisasi dan pendidikan, yakni keluarga berperan memberikan pendidikan berdasarkan tahap perkembangannya, yang bertujuan untuk mencetak manusia yang berkualitas di lingkungan dan kehidupan di masa yang akan datang. Keluarga pada dasarnya adalah tempat pertama dan utama untuk memberikan pendidikan kepada anggota keluarganya. Pendidikan pertama dan utama anak diawali sejak anak berada di lingkungan keluarga, khususnya didominasi oleh peran sang ibu ${ }^{12}$. Selain itu, terdapat beberapa peran dalam orang tua dalam pendidikan anak-anaknya yaitu dalam membimbing sikap serta keterampilan dasar, seperti pendidikan agama untuk patuh terhadap aturan, dan untuk pembiasaan yang baik.

Sebelum terjadinya pandemi tugas pendidikan akademik seringkali di limpahkan kepada lembaga pendidikan atau guru di sekolah, yang rata-rata berorientasi pada penyampaian materimateri pelajaran tertentu. Namun situasi pandemi sekarang ini, mendorong orang tua untuk lebih berperan. Nilai edukasi atau pendidikan yang diberikan orang tua hendaknya berorientasi pada penanaman karakter positif yang dapat menunjang tercapainya karakter anak yang diharapkan. Terkait peran orang tua dalam mendampingi anak belajar di rumah pada dasarnya mengembalikan fitrah awal orang tua, yakni pendidik pertama dan utama dikeluarganya. Orang tua memiliki peran untuk mendidik anak dan menjadi guru di rumah bagi anak-anaknya

\footnotetext{
${ }^{12}$ Hero, H. Sni, M. E. 2018. Peran Orang Tua dalam Meningkatkan Motivasi Belajar Siswa Kelas V di Sekolah Dasar Inpres Iligetang. Jurnal Riset Pendidikan Dasar. Vol. 1. No. 2, Oktober. Hal. 130.

45 | Jurnal Auladuna
} 
khususnya ibu. Ibu merupakan madrasah pertama bagi anak yaitu mulai dalam kandungan sampai anak menikah ataupun sampai akhir hayat.

\section{Memelihara dan Mengamalkan Nilai Keagamaan}

Keluarga atau orang tua menjadi tempat utama untuk menanamkan nilai-nilai keagamaan. Keluarga mengembangkan kehidupannya tidak hanya dengan memahami materi saja, tetapi juga dengan mengamalkan serta melaksanakan nilai-nilai dan norma agama dengan penuh iman dan taqwa kepada Tuhan. Contohnya seperti saling berbagi dan membantu kepada orang yang sedang kesusahan karena dampak pandemi saat ini. Orang tua perlu mengajarkan kepada anak bahwa dalam hal sesulit apapun tidak boleh berbuat hal-hal yang menyimpang dari nilai-nilai agama serta tetap wajib melaksanakan hal-hal yang diperintahkan agama.

Memelihara dan mengamalkan nilai-nilai agama merupakan salah satu dari dimensi pengaturan diri yang bijaksana dalam pola asuh orang tua kepada anaknya, apalagi di Indonesia yang sangat menjunjung tinggi nilai-nilai keagamaan. Dalam hal ini orang tua perlu memiliki keterampilan dalam memberikan arahan, membiasakan ibadah, dan menyampaikannya sesuai dengan perkembangan anak. Pembiasaan ibadah harus diterapkan anak sejak dini serta memberikan arahan positif mengenai dampak positif dalam beribadah. Dalam mencapai pengaturan diri yang baik khususnya dalam melaksanakan niali-nilai keagamaan, anak-anak perlu memiliki kematangan sosial emosi yang baik. Untuk dapat mencapainya maka orang tua perlu memiliki sikap toleran, suportif, dan terampil dalam mengatur emosi dan pola pikir seorang anak.

\section{Hasil Penelitian}

Tujuan dari penelitian ini adalah untuk mendapatkan informasi tentang peran orangtua dalam pendampingan pembelajaran online selama pandemi covid-19. Semua jawaban dari responden adalah kutipan asli sesuai dengan jawaban pertanyaan yang diberikan. Hasil dari pertanyaan "Bagaimana sikap anak Anda selama pembelajaran online dilaksanakan di rumah?", ada $80 \%$ responden yang menjawab "lebih banyak bermain daripada belajar" dan 20\% menjawab "lebih suka belajar". Berdasarkan jawaban tersebut terlihat bahwa waktu belajar dari rumah lebih sedikit dari pada waktu belajar di sekolah. Hal ini memerlukan peran dan pengawasan orangtua dalam mengarahkan kewajiban anak.

Pertanyaan "Apakah kendala yang di alami pada saat pembelajaran online berlangsung?" responden menjawab 90\% "tidak ada kendala" dan 10\% menjawab "sinyal atau kuota internet". Hal tersebut membuktikan bahwa kalangan masyarakat sudah tidak asing 
dengan teknologi khususnya smartphone atau laptop yang merupakan media utama pembelajaran online. Pemerintah yaitu Kementerian Pendidikan juga telah memberikan bantuan berupa kuota internet gratis yang dibagikan ke sekolah-sekolah demi terlaksananya pembelajaran online dengan baik. Beberapa perusahaan yang bergerak di bidang jasa layanan teknologi informasi dan komunikasi juga memberikan bantuan kartu perdana atau paket kuota gratis ke beberapa lembaga pendidikan seperti sekolah dan perguruan tinggi. Wifi dengan paket murah juga banyak ditawarkan oleh beberapa perusahaan demi terwujudnya pendidikan dalam pembelajaran online yang mudah dan murah diakses oleh beberapa kalangan masyarakat.

Pertanyaan "Apakah dengan pembelajaran online anak Anda dapat memahami materi yang telah di berikan?", terdapat 65\% yang menjawab "Ya" dan 35\% menjawab "Tidak". Artinya sekolah atau guru telah mengupayakan berbagai cara penyampaian materi pembelajaran yang mudah dipahami oleh siswa. Misalnya sepertimvideo atau media pembelajaran interaktif yang akan menarik minat siswa dalam pemahaman materi. Orang tua sangat diperlukan dalam hal ini, yaitu memotivasi anak untuk terus semangat dalam memahami materi yang diberikan guru. Peran orang tua dalam membantu pemahaman materi sangatlah penting. Jadi selain materi tersebut dijelaskan guru, hendaknya orang tua juga mengulangi penjelasan guru serta menekankan kepada anak secara berulang agar anak dapat memahaminya dengan mudah.

Pertanyaan "Apakah Anda selalu mendampingi anak saat pembelajaran online berlangsung?", ada 70\% yang menjawab "Selalu" dan 30\% menjawab "Kadang-kadang". Jawaban tersebut dikarenakan banyak orangtua yang bekerja di luar rumah sehingga tidak bisa mendampingi anak secara optimal. Tetapi dengan orang tua yang bekerja di luar rumah tidak serta merta membiarkan anak belajar sendiri tanpa adanya dampingan. Orang tua bisa menanyakan atau membantu dalam mengerjakan tugas dari guru saat orang tua telah pulang kerja atau setelah tiba di rumah.

Pertanyaan "Apa yang yang dilakukan Anda saat mengalami kesulitan ketika mendampingi anak dalam pembelajaran online?", 70\% responden menjawab "Mencari referensi di internet", 20\% menjawab "Bertanya kepada sesama walimurid", dan 10\% menjawab "Bertanya kepada guru". Hal tersebut mengartikan bahwa orangtua sudah mandiri dan memahami banyak cara dalam membantu anak mengerjakan tugas atau memahami materi yang diberikan guru. Bisa mencari informasi atau referensi di internet, bertanya kepada sesama wali murid, bertanya kepada teman atau kerabat yang dianggap ahli di bidangnya. 
Eka Rahayn

Vivin Agustin Anggraini

Siti Nurbasanatul Islam

Pertanyaan "Bagaimana sikap Anda saat anak melaksanakan pembelajaran online?”, dari 100 responden 97\% menjawab "Selalu mendampingi anak dan membantu dalam mengerjakan tugas" dan 3\% menjawab "Membiarkan anak dalam pembelajaran online sendiri”. Hal tersebut membuktikan bahwa orangtua sangat peduli dan memberikan perhatian penuh kepada anak saat anak melaksanakan pembelajaran online.

Pertanyaan "Apakah sesama wali murid saling berbagi untuk mendapatkan informasi terhadap tugas anak Anda?", 100\% menjawab "Ya" yang artinya semua wali murid saling berkomunikasi dan memberikan informasi mengenai materi pembelajaran atau tugas yang diberikan guru. Hal tersebut menunujukkan pola interaksi positif antar sesama wali murid dalam membantu anak belajar dan memenuhi kebutuhan pendidikan.

Berdasar pada jawaban orangtua di atas bahwa keberhasilan seorang anak dalam pembelajaran online di masa pandemi Covid-19 sangat ditentukan oleh peran orang tua. Peran yang dibutuhkan diantaranya memberikan fasilitas berupa smartphone atau laptop serta kuota internet, pendampingan dalam belajar online, motivasi dan arahan serta bantuan terhadap pemahaman materi atau pengerjaan tugas sangat dibutuhkan anak dalam pemenuhan kebutuhan pendidikan di bidang akademik. Banyak orangtua yang bekerja di luar rumah tetapi tetap meluangkan waktunya untuk mendampingi anak saat pembelajaran online berlangsung. Hal tersebut dapat dilakukan orangtua sepulang kerja tanpa lelah mendampingi anak dalam pembelajaran online di rumah.

\section{Penutup}

Hasil penelitian menunjukkan bahwa secara umum peran orang tua yang muncul selama pandemi Covid-19 adalah sebagai pembimbing, pendidik, penjaga, pengembang dan pengawas serta secara spesifik menunjukkan bahwa peran orang tua adalah menjaga dan memastikan anak untuk menerapkan hidup bersih dan sehat, mendampingi anak dalam mengerjakan tugas sekolah, melakukan kegiatan bersama selama di rumah, menciptakan lingkungan yang nyaman untuk anak, menjalin komunikasi dengan anak, bermain bersama anak, menjadi panutan bagi anak, memberikan pengawasan pada anggota keluarga, menafkahi dan memenuhi kebutuhan keluarga, membimbing dan memotivasi anak, memberikan edukasi, memelihara dan mengamalkan nilai keagamaan. 


\section{Referensi}

Hero, H. Sni, M. E. 2018. Peran Orang Tua dalam Meningkatkan Motivasi Belajar Siswa Kelas V di Sekolah Dasar Inpres Iligetang. Jurnal Riset Pendidikan Dasar. Vol. 1. No. 2, Oktober. Hal. 129-139.

Peraturan Pemerintah Republik Indonesia Nomor 21 Tahun 1994: Tentang Penyelenggaraan Pembangunan Keluarga Sejahtera, Pub. L. No. 21. 1994.

Rumbewas, S. F., Laka, B. M.., Moekbun, N. 2018. Peran Orang Tua dalam Meningkatkan Motivasi Belajar Peserta Didik di SD Negeri Saribi. Jurnal EduMatSains. Vol. 2. No. 2, Januari, 201-212.

Sari, Diana. 2017. Peran Orang Tua dalam Memotivasi Belajar Siswa. Prosiding Seminar Nasional. Universitas PGRI Palembang. November. 40-43.

Umar, Munirwan. 2015. Peranan Orang Tua dalam Peningkatan Prestasi Belajar Anak. Jurnal ilmiab edukasi. Vol. 1. No. 1, Juni, 20-28.

Warisah, Yusmi. 2015. Pentingnya "Pendampingan Dialogis" Orang Tua dalam Penggunaan Gadget Pada Anak Usia Dini. Prosiding Seminar Nasional Pendidikan. Universitas Muhammadiyah Ponorogo. November. Hal. 130-138.

Wulandari, Y., Kristiawan, M. 2017. Strategi Sekolah dalam Penguatan Pendidikan Karakter bagi Siswa dengan Memaksimalkan Peran Orang Tua. Jurnal Manajemen, Kepemimpinan, dan Supervisi Pendidikan. Vol. 2. No. 2, Juli, 290-302.

Yulianti, T. R. 2014. Peran Orang Tua dalam Mengembangkan Kreativitas Anak Usia Dini (Studi Kasus Pada Pos PAUD Melati 13 Kelurahan Padasuka Kecamatan Cimahi Tengah). Jurnal Empowerment. Vol. 4. No. 1, Februari, 11-24. 